\title{
Study and assessment of clusters activity effect on regional economy
}

\author{
A. Babkin ${ }^{1, *}, Y$. Vertakova ${ }^{2}, V$. Plotnikov $^{3}$ \\ ${ }^{1}$ Peter the Great St. Petersburg Polytechnic University 195251, Polytechnicheskaya str., 29, Saint Petersburg, Russia \\ ${ }^{2}$ Southwest State University 305040, 50 Let Oktyabrya str., 94, Kursk, Russia \\ ${ }^{3}$ St. Petersburg State University of Economics 191023, Sadovaya str., 21, Saint Petersburg, Russia
}

\begin{abstract}
The cluster approach, i.e., forming basic innovative and industrial clusters is widely applied in modern Russian conditions for the development of the economy. These actions are considered as effective measures for implementing the economic policy stimulating regional development by federal and regional authorities. The analysis we carried out showed that the quantitative approach for assessing the efficiency of cluster creation and performance is still insufficiently used. In this paper we establish and quantitatively estimate the influence cluster have on the regional economy using regression analysis with an example of a number of Russian regional clusters. Expanding the practice of creation and the state support of clusters taking into account the revealed quantitative dependences estimating their efficiency is suggested. We have advanced the hypothesis that clustering has a positive influence on regional economy, and confirmed this influence by means of quantitative methods using representative datasets. Our study of course had a selective character as it is not possible to carry out the calculations for all the existing clusters and cluster initiatives of Russia and discuss the results within a single article. At the same time, following the analysis we performed, we concluded that it is effective to initiate cluster creation in Russian regions. It is shown that cluster activity is capable to have of having a positive impact on GRP growth and the budgetary income in the region. Along with that, we note the dissimilarities in the multiplying influence of clusters on the regional development, its dependence on territorial and branchspecifics that will be the direction for a further indepth study.
\end{abstract}

\section{Introduction}

A cluster as an object of an economic agglomeration of interconnected enterprises in a certain area has been known since the time of the handicraft industry. At that, for the origin of the cluster approach (1830-1890), the economic science is obliged to A. Marshall, who himself called clusters "localized industries" [1]. Later (18901950), the term "industrial districts" became widespread in literature. The most popular term today - "cluster" emerged much later. The notion of "cluster" is considered to be introduced into the economic relations theory by M. Porter (1998) [2]. M. Porter used the term "cluster" to analyze the structure and effectiveness of economic relations in industries and organizations. When analyzing competitiveness of a company, he paid special attention to its economic environment. Now, a cluster is considered as a separate economic system [3 9] and an integrated structure [10-12,14,18,20 ], which significantly affects both: the development of regional and sectoral economies and the national economy in general [13,15-19 and others].

The theoretical foundation of the cluster concept originated at the beginning of the XIX century in the works on economics of agglomeration by J. Von Thunen and his followers W. Launhardt and A. Weber, who studied the enterprise and its location in the economic space in relation to sources of raw materials and sales markets and also factors that influence it [Von Thunen, 1826; Launhardt, 1882; Weber, 1909] (table 1).

Table 1. Characteristics of the cluster theories based on [3-11, 17-20].

\begin{tabular}{|c|l|l|}
\hline $\begin{array}{c}\text { Theories } \\
\text { of the } \\
\text { cluster } \\
\text { approach }\end{array}$ & Authors & \multicolumn{1}{|c|}{ Properties of a cluster } \\
\hline $\begin{array}{l}\text { Agglomera } \\
\text { tion theory }\end{array}$ & $\begin{array}{l}\text { Marshall, } \\
\text { Ooover, }\end{array}$ & $\begin{array}{l}\text { Geographic proximity of firms } \\
\text { and the influence of the triad of } \\
\text { external scale economies: labor } \\
\text { availability, supporting and }\end{array}$ \\
\hline
\end{tabular}




\begin{tabular}{|c|c|c|}
\hline & & $\begin{array}{l}\text { auxiliary industries, } \\
\text { specialization of different firms } \\
\text { at different stages of the } \\
\text { production process, allowance } \\
\text { for transport costs. }\end{array}$ \\
\hline $\begin{array}{l}\text { New } \\
\text { economic } \\
\text { geography } \\
\text { "New } \\
\text { industrial } \\
\text { districts" } \\
\end{array}$ & $\begin{array}{l}\text { Krugman, } \\
\text { Saksenina } \\
\mathrm{n}\end{array}$ & $\begin{array}{l}\text { Geographic proximity of firms, } \\
\text { the influence of the triad of } \\
\text { external scale economies, the } \\
\text { influence of information and } \\
\text { knowledge spillovers, } \\
\text { allowance for transaction costs }\end{array}$ \\
\hline $\begin{array}{l}\text { Industrial } \\
\text { complex }\end{array}$ & $\begin{array}{l}\text { Hoover, } \\
\text { Isard }\end{array}$ & $\begin{array}{l}\text { The interaction of firms within } \\
\text { one industry in the form of } \\
\text { "buyer-seller", } \\
\text { consumer" }\end{array}$ \\
\hline $\begin{array}{l}\text { Industrial } \\
\text { cluster }\end{array}$ & $\begin{array}{l}\text { Gordon, } \\
\text { McCann }\end{array}$ & $\begin{array}{l}\text { The interaction of firms within } \\
\text { several interconnected } \\
\text { industries both in terms of the } \\
\text { production process of goods } \\
\text { and services and knowledge } \\
\text { flows }\end{array}$ \\
\hline $\begin{array}{l}\text { Competitiv } \\
\text { eness } \\
\text { theory by } \\
\text { M. Porter }\end{array}$ & M. Porter & $\begin{array}{l}\text { The influence on the cluster's } \\
\text { successfulness of interrelations } \\
\text { between factors inside the } \\
\text { "competitiveness brilliant" } \\
\text { region: strategy, structure, } \\
\text { competitiveness; demand } \\
\text { conditions; factorial conditions; } \\
\text { linked industries; state } \\
\text { intervention. }\end{array}$ \\
\hline $\begin{array}{l}\text { Neo- } \\
\text { competitiv } \\
\text { eness of M. } \\
\text { Porter }\end{array}$ & $\begin{array}{l}\text { M. } \\
\text { Enright, } \\
\text { Solvel, } \\
\text { van } \\
\text { Grunsven, } \\
\text { van } \\
\text { Egeraat, } \\
\text { Clancy }\end{array}$ & $\begin{array}{l}\text { Taking into account the } \\
\text { cluster's lifecycle, the influence } \\
\text { of globalization and global } \\
\text { markets, transnational } \\
\text { companies, participation of } \\
\text { foreign investors, specialized } \\
\text { cooperative and competitive } \\
\text { interrelations }\end{array}$ \\
\hline $\begin{array}{l}\text { Innovative } \\
\text { system } \\
\text { theory }\end{array}$ & $\begin{array}{l}\text { Frimen, } \\
\text { Lundvall, } \\
\text { Edquist, } \\
\text { Cook, } \\
\text { Morgan }\end{array}$ & 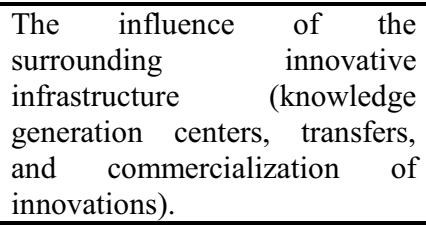 \\
\hline $\begin{array}{l}\text { Network } \\
\text { theory }\end{array}$ & $\begin{array}{l}\text { Feser, } \\
\text { Sviimi, } \\
\text { Perucci, } \\
\text { Harisson }\end{array}$ & $\begin{array}{l}\text { The flexibility of the cluster's } \\
\text { organizational structure, a } \\
\text { special role of the social capital } \\
\text { (trust, solidarity) and the } \\
\text { institutes which ensure stable } \\
\text { connections between firms, the } \\
\text { processes of mutual and } \\
\text { constant learning }\end{array}$ \\
\hline $\begin{array}{l}\text { Innovative } \\
\text { clusters } \\
\text { theory }\end{array}$ & $\begin{array}{l}\text { Feldman, } \\
\text { Audretsch } \\
\text { Carlson, } \\
\text { Johnson }\end{array}$ & $\begin{array}{l}\text { Commitment to creating an } \\
\text { innovative product by } \\
\text { interaction between the cluster's } \\
\text { members (competing firms), } \\
\text { external knowledge sources } \\
\text { based on formal and informal } \\
\text { cooperation processes }\end{array}$ \\
\hline
\end{tabular}

However, many researchers [Bathelt, 1998; Ketels, 2003; Krugman, 1991; Scott \& Storper, 1992; Audretsch, 1998] think that it was A. Marshall who, in his work "Principles of Economics" [A. Marshall, 1890], was first to empirically prove that productivity of firms and the results of their activity directly depend on their location and geographic proximity of economic agents.
The rise of clusters of our period (starting from the 1970 's) is mainly caused by disintegration processes of vertically-integrated companies and structures [10-12, $20]$, the main reason for which was a radical increase in production complexity - first of all in the machineryproducing industry. The number and range of semifinished products and components used in assembling final products were greatly increased and expanded. Under these conditions, centralization of all industrial sites within one vertically-integrated structure ceased to be a realistic choice. The alternative to this is cooperation of independent producers on a mutually beneficial basis, i.e. a cluster. As the founder of the cluster approach, M. Porter defines the cluster as "a geographically proximate group of interconnected companies and associated institutions in a particular field, linked by commonalities and externalities" [2]. The given definition fully reflects the cluster's essence as an economic and geographical unit. Besides, it is highlighted that as a rule, a cluster is not something separate but a part of a single system. Here it should be supposed that within a system there is some kind of interconnection and interconditionality determining their successful functioning.

Taking into account distinctive features, the following interpretation is offered for a cluster: it is an industrially limited group of economic agents, innovative formations, state administrative and scientific-educational institutions which combine formal independence and internal competitiveness with cooperation and a shared control center, the purpose of which lies in reprocessing high-tech products and industries and achieving a general synergy effect.

Cluster initiatives are widely adopted in modern Russia. According to the Russian cluster observatory (http://map.cluster.hse.ru/list — the estimates on the quantity of clusters in the Russian Federation, but it isn't concrete numbers, and in qualitative result. Clusters became a noticeable phenomenon, especially at the regional level of the national economy. Because of this, many publications are dedicated to studying them $[1,3$, $4,7,8,11-15$, etc.] (we should note that the authors of this article also made a certain contribution to studying these issues [3, 7, 8, 11, 12, 17, 20etc.]).

\section{Problem statement}

While we do not intend to analyze cluster and the publications dedicated to them in detail, we should point out on circumstance that is important in our opinion: cluster organization of economic associations is confirmed to be rather effective both in theory and in practice. This article is dedicated to critical consideration of this statement. We willuse methods of quantitative analysis for assessing the efficiency of cluster organization of economic activity.

\section{Results of the study}

We used the above-mentioned Map of clusters of Russia as basic data for carrying out calculations. Since 
it contains numerous objects and our computing and temporal resources were limited, we selected four clusters from the entire set (Tab. 1). We selected the clusters for study based on the premise that if some clusters existed in the same branch, preference was given to the cluster with a higher level of organizational development or functioning during a longer period. We also paid attention to the existence of necessary statistical information on clusters. Besides, when forming our selection, we strived to make it cover various non-related branches to obtain more objective results.

Table 1. Selection of clusters for quantitative analysis.

\begin{tabular}{|l|c|c|l|}
\hline \multicolumn{1}{|c|}{$\begin{array}{c}\text { Cluster, } \\
\text { region }\end{array}$} & Branch & $\begin{array}{c}\text { Level of } \\
\text { organization } \\
\text { al } \\
\text { development }\end{array}$ & $\begin{array}{l}\text { Year } \\
\text { of } \\
\text { establis } \\
\text { hment }\end{array}$ \\
\hline $\begin{array}{l}\text { Textile } \\
\text { cluster of } \\
\text { the Ryazan } \\
\text { Oblast }\end{array}$ & $\begin{array}{c}\text { Production of } \\
\text { textile products, } \\
\text { clothes, footwear, } \\
\text { leather products }\end{array}$ & Initial & 2014 \\
\hline $\begin{array}{l}\text { Power } \\
\text { cluster } \\
\text { Tula } \\
\text { region }\end{array}$ & $\begin{array}{c}\text { Electricity } \\
\text { generation } \\
\text { electric } \\
\text { equipment }\end{array}$ & Initial & 2012 \\
\hline $\begin{array}{l}\text { Innovative } \\
\text { territorial } \\
\text { timber } \\
\text { industry } \\
\text { cluster }\end{array}$ & $\begin{array}{c}\text { Forestry and } \\
\text { woodworking; } \\
\text { pulp and paper } \\
\text { production }\end{array}$ & Average & 2014 \\
\hline $\begin{array}{l}\text { Dairy } \\
\text { cluster of }\end{array}$ & $\begin{array}{l}\text { Agriculture and } \\
\text { fishery }\end{array}$ & Initial & 2015 \\
\hline
\end{tabular}

S our ce: data of the Russian cluster observatory (http://map.cluster.hse.ru/list).

We considered the following resultant indicators: level of economic development of the region, which is estimated quantitatively through GRP per capita (thousands of rubles), as well as the income of the budget (the average per capitaindicator measured in thousands of rubles per person per year was also considered). We estimated how these indicators changed under the influence of cluster initiatives introduced by theregions under consideration. Since the assessed clusters operate in various branches of specialization, we used similar indicators for quantitative assessment. These included the volume of investment and output, but considered not for the region as a whole but only for branches of cluster specialization (Figure 1). Thus, the average per capita estimates measured in thousands of rubles were also used.

Information from statistical collections of Rosstat was used as basic data for calculations. The period from 2004 to 2014 was covered. The regression analysis method was used which allows to estimate the extent of mutual influence of the considered indicators with a sufficiently highdegree of accuracy.

\begin{tabular}{|c|c|c|c|}
\hline Ryazan & Tula & Arkhange & Vologd \\
\hline \multicolumn{4}{|c|}{ GRP per capita $\left(\mathrm{y}_{1}\right)$} \\
\hline 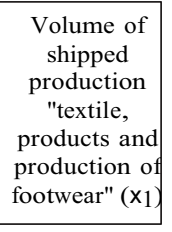 & \begin{tabular}{|c|} 
Volume of \\
shipped \\
production \\
"distribution \\
of electric \\
power, gas \\
and water" \\
$(\mathrm{x} 1)$ \\
\end{tabular} & $\begin{array}{l}\text { Volume of } \\
\text { shipped } \\
\text { production } \\
\text { "pulp-and- } \\
\text { paper } \\
\text { production" } \\
(\mathrm{x} 1) \\
\end{array}$ & $\begin{array}{c}\text { Production } \\
\text { of } \\
\text { agricultural } \\
\text { products (x1) }\end{array}$ \\
\hline $\begin{array}{l}\text { into fixed } \\
\text { capital of } \\
\text { processing } \\
\text { production } \\
(\mathrm{x} 2)\end{array}$ & $\begin{array}{l}\text { Investments } \\
\text { into fixed } \\
\text { capital of } \\
\text { production, } \\
\text { transfer of } \\
\text { power (x2) }\end{array}$ & $\begin{array}{l}\text { Investments } \\
\text { of processing } \\
\text { production } \\
\checkmark\end{array}$ & $\begin{array}{l}\text { Investments } \\
\text { into fixed } \\
\text { capital of } \\
\text { agriculture, } \\
\text { hunting and } \\
\text { forestry }\left(x_{2}\right)\end{array}$ \\
\hline \multicolumn{4}{|c|}{ Budget income $\left(\mathrm{y}_{2}\right)$} \\
\hline
\end{tabular}

Fig. 1. Resultant and factorial indicators for the analysis of clusters.

Linear one- and two-factorial equations of regression were constructed, given in Tab. 2 (only the dependences which have a high degree of accuracy, estimated by the determination coefficient R2, are presented in the table).

In Tab. 2 indicators: GRP per capita (y1), Budget income (y2)

Table 2. Regression dependences of indicators of analyzed clusters and regions.

\begin{tabular}{|l|l|l|}
\hline Oblast & \multicolumn{1}{|c|}{ Regression equation } & $\mathbf{R}^{\mathbf{2}}$ \\
\hline Ryazan & $\mathrm{y}_{1}=21.488+13.45209 \mathrm{x}_{2}$ & 0.86 \\
& $\mathrm{y}_{1}=17.385+5.776 \mathrm{x}_{1}+13.01 \mathrm{x}_{2}$ & 0.88 \\
\cline { 2 - 3 } & $\mathrm{y}_{2}=6.03933+2.03368 \mathrm{x}_{2}$ & 0.82 \\
& $\mathrm{y}_{2}=5.829+0.296 \mathrm{x}_{1}+2.011 \mathrm{x}_{2}$ & 0.82 \\
\hline \multirow{3}{*}{ Tula } & $\mathrm{y}_{1}=11.89458+11.858 \mathrm{x}_{1}$ & 0.79 \\
& $\mathrm{y}_{1}=85.95291+13.198 \mathrm{x} 2$ & 0.67 \\
& $\mathrm{y}_{1}=15.441+8.267 \mathrm{x}_{1}+7.116 \mathrm{x}_{2}$ & 0.91 \\
\cline { 2 - 3 } & $\mathrm{y}_{2}=1.885+2.206 \mathrm{x}_{1}$ & 0.76 \\
& $\mathrm{y}_{2}=16.144+2.376 \mathrm{x}_{2}$ & 0.63 \\
& $\mathrm{y}_{2}=2.482+1.602 \mathrm{x}_{1}+1.197 \mathrm{x}_{2}$ & 0.89 \\
\hline \multirow{4}{*}{$\begin{array}{l}\text { Arkhangel } \\
\text { sk Oblast }\end{array}$} & $\mathrm{y}_{1}=95.97+5.906 \mathrm{x}_{1}$ & 0.62 \\
& $\mathrm{y}_{1}=96.077+5.91 \mathrm{x}_{1}-0.03 \mathrm{x}_{2}$ & 0.62 \\
\cline { 2 - 3 } & $\mathrm{y}_{2}=15562+0.905 \mathrm{x}_{1}-0.401 \mathrm{x}_{2}$ & 0.62 \\
\hline \multirow{4}{*}{ Vologda } & $\mathrm{y}_{1}=-53.685+18.937 \mathrm{x}_{1}$ & 0.88 \\
Oblast & $\mathrm{y}_{1}=54.295+87.771 \mathrm{x}_{2}$ & 0.63 \\
& $\mathrm{y}_{1}=-49.738+16.812 \mathrm{x}_{1}+14.602 \mathrm{x}_{2}$ & 0.88 \\
\cline { 2 - 3 } & $\mathrm{y}_{2}=9.864+12.311 \mathrm{x}_{2}$ & 0.70 \\
& $\mathrm{y}_{2}=-3.153+2103 \mathrm{x}_{1}+3.156 \mathrm{x}_{2}$ & 0.93 \\
\hline
\end{tabular}




\section{Analysis of the received results}

The analysis of the obtained dependences given in the table allows to draw conclusions as to the extent to which the growth of investments into fixed capital and production volumes influences the amount of the gross regional product and the budget income of the considered regions with clusters:

1. Ryazan Oblast (textile cluster):

- with the investments into the fixed capital of the processing industry increased by 1 thousand rub., the GRP increases by 16565 rub., i.e., the coefficient of a multiplication in this case exceeds 16.5;

- with the production volume for «textile, sewing production, leather products and production of footwear» increased by 1 thousand rub., the GRP will increase by $5776 \mathrm{rub}$. at the same volume of investment into fixed capital. The increase in the volume of investments into fixed capital of the processing industry by 1 thousand rub. at the same volume of production implies GRP growth by 13010 rub., i.e. the multiplying influence of investments on the GRP exceeds a similar influence of the output increase of the cluster's enterprises by more than two times. At the same time, the production in the cluster is observed to experience a fast growth by almost 5 times with respect to the overall GRP;

- with the volume of investments into fixed capital of the processing industry increased by 1 thousand rub., the income of the budget will increase by 20337 rub., i.e., the coefficient of multiplication in this case exceeds 20.3. It is obvious that granting benefits for the investment activity of textile enterprises is economically justified;

- with the production volume for «textile, sewing production, leather products skin and production of footwear» increased by 1 thousand rub., the income of the budget will increase by 296 rub. at the same volume of investments into fixed capital. The increase in the volume of investments into fixed capital of the processing industry by 1 thousand rub. at the same volume of production leads to the income of the budget increasing by $2011 \mathrm{rub}$.

Thus, the performance of the enterprises from the «textile, sewing production, leather products and production of footwear» cluster in the Ryazan Oblast has a considerable positive impact on the growth of the GRP and the income of the budget, and investments into fixed capital of the processing industry pay off, having a substantial positive impact on the growth of these indicators. Therefore, the creation of a textile cluster in the Ryazan Oblast was expedient; this cluster has a substantial positive multiplying impact on the regional economy. In this regard, it is possible to conclude that the textile cluster of the Ryazan Oblast is effective.

2. Tula Oblast (power cluster):

- with the production volume for «production and distribution of the electric power, gas and water» increased by 1 thousand rub., the GRP will increase by more than by 11 times, i.e., by 11858 rub.;

- with the investments into fixed capital of production, transfer and distribution of the electric power, gas and water increased by 1 thousand rub., the GRP will increase even more considerably by 13198 rub.;

- with the production volume for «production and distribution of the electric power, gas and water» increased by 1 thousand rub., the GRP will increase by $8267 \mathrm{rub}$ at the same volume of investments into fixed capital. The increase in the volume of investment into the fixed capital of production, transfer and distribution of the electric power, gas and water by 1 thousand rub. at the same production volume leads to an increase of the GRP by $7116 \mathrm{rub}$; - with the production volume for «production and distribution of the electric power, gas and water» increased by 1 thousand rub., the income of the budget will increase by $2206 \mathrm{rub}$;

- with the volume of investments into fixed capital for production, transfer and distribution of the electric power, gas and water increased by 1 thousand rub., the income of the budget will increase by 2376 rub;

- with the production volume for «production and distribution of the electric power, gas and water» increased by 1 thousand rub., the income of the budget will increase by 1602 rub at the same volume of investments into fixed capital. The increase in the volume of investments into the fixed capital for production, transfer and distribution of the electric power, gas and water by 1 thousand rub. at the same production volume leads to an increase of the income of the budget by $1197 \mathrm{rub}$.

Based on the obtained results, we can draw conclusions for the power cluster of the Tula Oblast similar to the above-formulated ones for the textile cluster of the Ryazan Oblast. Quantitative estimates of the cluster's impact on the indicators of the regional economy in the Tula Oblast are slightly lower than in the Ryazan Oblast. Nevertheless, the economic performance (investments and output) of the cluster's enterprises also has a positive multiplying impact on the regional economy. Quantitative distinctions which we found can be caused by territorial, industrial, technological, institutional and other factors; detailed analysis of these factors is outside the scope of this article.

3. Arkhangelsk Oblast (timber industry cluster): - with the production volume of the pulp-and- paper industry increased by 1 thousand rub., the GRP will increase by 5906 rub. This means that this type of production is closely tied with the GRP, and the coefficient of multiplication is almost equal to 6 units;

- with the production volume of the pulp-and- paper industry increased by 1 thousand rub., the GRP will increase by 5910 rub. at the same volume of investments into fixed capital; the increase in the volume of investments into the fixed capital of the 
processing industry by 1 thousand rub. at the same volume of production will cause a reduction of the GRP by 0.03 thousand rubles. Though this reduction is insignificant (it is possible to explain it by statistical error), but it is still present and thus demands further study;

- with the production volume of the pulp- and-paper industry increased by 1 thousand rub., the income of the budget will increase by 905 rub. (a very significant increase which can indicate, firstly, the considerable multiplying influence of the pulp-andpaper industry on the economic activity in the Arkhangelsk Oblast, and, secondly, the raised tax burden of this branch) at the same volume of investment into fixed capital. With the volume of investment into fixed capital of the processing industry increased by 1 thousand rub. at the same volume of production, the income of the budget will be reduced by $401 \mathrm{rub}$. It is worth focusing on this last result: the mechanism of its formation is not quite clear. It then follows that the growth of investment activity in the Arkhangelsk Oblast is undesirable from the positions of budget formation. It reduces the income of the budget. This result cannot be explained by calculation errors or inaccuracies of the basic data (as we did in the previous subparagraph): the ratio of investment growth to the decrease in the budgetary income equals $5: 2$ and is rather significant.

The obtained results testify that the performance of the timber industry cluster in the Arkhangelsk Oblast has a positive impact on the economy of the region, increasing the GRP and the income of the budget. However, investments into the fixed capital of the processing industry in this case are not effective as the increase in their volume leads to a reduction of both the GRP and the income of the budget. Thus, the Pomorinnovales innovative territorial timber industry cluster can be considered effective from positions of development of the regional economy, but a revision of the investment policy of the region, and improvement of its mechanisms are necessary.

\section{Vologda Oblast (dairy cluster):}

- with the production volume of the agricultural industry increased by 1 thousand rub., the GRP will increase by 18937 rub. In this case we recorded the greatest numerical value of the multiplier, 18.9. This means that the development of the agricultural industry (if we judge by the considered selection of clusters) has the greatest multiplying impact on the regional economy. We connect it with the circumstance that the creation of agroclusters means not only production, but also processing of the agricultural products in the territory of the region where the cluster is located, which in turn generates additional types of economic activity, additional workplaces and added value;

- with the volume of investments into the fixed capital of agriculture, hunting and forestry increased by 1 thousand rub., the GRP will increase by 87771 rub. This means that here we observe an even larger multiplying impact on the development of the regional economy than the one we considered in the previous subparagraph. This confirms the conclusion about the priority of state support of production and processing of agricultural products. The crux of the matter here is not in solving social (support of the rural areas) or political (ensuring food security) tasks, but in purely economic reasons. This support generates a very high economic effect;

- with growth of volume of release of agricultural production increased by 1 thousand rub., GRP will increase for $16812 \mathrm{rub}$ at the same volume of investment into fixed capital. The increase in the volume of investment into fixed capital of agriculture, hunting and forestry increased by 1 thousand rub., at the same volume of production, will cause increase of GRP on 14602 thousand rubles. Thus, and at joint increase in two influencing factors considered by us, the resultant variable shows very high sensitivity;

- with the volume of investments into the fixed capital of agriculture, hunting and forestry increased by 1 thousand rub., the income of the budget will increase by $12311 \mathrm{rub}$. This circumstance seems very important to us. It is an additional argument for state support (including within the existing institutional regulations and financial ) of agrocluster development;

- with the volume of agricultural production increased by 1 thousand rub., the income of the budget will increase by 2013 rub at the same volume of investments into fixed capital. The volume of investments into the fixed capital of agriculture, hunting and forestry increased by 1 thousand rub. at the same volume of production will cause an increase of the income of the budget by 3156 thousand rubles.

Thus, calculations showed that the performance of the agricultural enterprises in the Vologda Oblast and investments into the working capital of agriculture, hunting and forestry have a very significant positive impact on the growth of the GRP and the income of the budget. It follows from this that the dairy cluster created in the region functions in an effective specialization branch, and the full support of its development is necessary and economically expedient.

\section{Conclusions}

Summing up the results, we will note that the hypothesis we advanced about the positive influence that clustering has on the regional economy was confirmed quantitatively. This influence was proved by means of quantitative methods using enough representative datasets (covering 11 years). Our study undoubtedly had a selective character: it does not seem possible to carry out calculations for all cluster initiatives existing in Russia and to discuss their 
results within a single article. At the same time, following the results of the analysis we carried out, it is possible to draw a conclusion on the efficiency of creating clusters in Russian regions. Cluster activity is capable of having a positive impact on the growth of GRP and the budgetary income in the region. Along with it, we noticed differences in the multiplying influence of clusters on regional development, and its dependence on territorial and branch specifics. Apparently, this question requires further in-depth study.

The research is realised by grant № 26.3546.2017 "Development fundamentals of analysis and prediction of structural and dynamic parameters of the regional economy based on the integration of the Russian and world experience of management of territorial development and modern scientific doctrines".

\section{References}

1. A. Marshall, Principles of economics (Publishing house: Progress, Moscow, 1993)

2. M.E. Porter, Harvard Business Review, 76(6), 77-90 (1998)

3. P.A. Arkin, A.G. Golubev, News of the St. Petersburg state economic university, 58-62 (2014)

4. A.V. Babkin, A.O. Novikov, St. Petersburg State Polytechnical University Journal. Economics, 1(235), 9-29 (2016). DOI: 10.5862/JE.235.1.

5. D.P. Badgers, V.S. Kudryashov, Formation of an industrial cluster: theoretical and methodical aspects: monograph (St. Petersburg, 2014)

6. E.V. Borodkina, I.E. Risin, Public administration by processes of a clustering of social and economic space of the region: monograph (Publishing house of VGPU, Voronezh, 2011)
7. Yu.V. Vertakova, V.A. Plotnikov, Economy and management, 3(125), 10-18 (2016)

8. Yu.V. Vertakova, Yu.S. Polozhentseva, M.Yu. Hlynin, Technical and technological problems of service, 1(27), 92-99 (2014)

9. A. Babkin, T. Kudryavtceva, S. Utkina, World Applied Sciences Journal, 28(10), 1408-1413 (2013)

10. Ya.S. Gorelova, News of the St. Petersburg state economic university, 6, 103-105 (2015)

11. A.V. Babkin, Cluster structure of an industrial economy (2014): the monograph (St. Petersburg state polytechnical university, St. Petersburg, 2014)

12. V.A. Carpenters, P.V. Sergeyev, S.V. Timofeeva, News of Southwest state university. Series: Economy. Sociology. Management, 2, 92-97 (2011)

13. M.G. Svetovtseva, Management of formation of an economic kernel of the region (Voronezh, 2004)

14. A.V. Babkin, S.V. Zdolnikova, Proceedings of The 28 th International Business Information Management Association Conference, 1-11 (2016)

15. Clusters and Regional Specialisation, On Geography, Technology and Networks (Pion, London, 1998)

16. M. Delgado, M. Porter, S. Stern, Clusters, Convergence, and Economic Performance (Institute for Strategy and Competitiveness, 2011)

17. A.V. Babkin, T.J. Kudryavtseva, Modern Applied Science, 9, 1, 109-118 (2015)

18. A.V. Babkin, Cluster economy and industrial policy: theory and tools: collective monograph (Polytechnic University Publishing, St.Petersburg, 2005)

19. G. Ahuja, C.M. Lampert, Strategic Management Journal, 22, 521-543 (2001).

20. G. Bell, Strategic Management Journal, 26, 287-295 (2005) 